\title{
MENAKAR EFEKTIVITAS PEMILU SERENTAK 2019
}

\author{
Triono \\ Program Studi Hubungan Internasional,Universitas Megou Pak Tulang Bawang \\ E-mail: triono.sr@gmail.com
}

\begin{abstract}
ABSTRAK
Gagasan terselenggaranya pemilihan umum serentak 2019 membawa konsekuensi politik secara nasional dan daerah. Putusan Mahkamah Konstitusi Nomor 14/PUU-XI/2013 perkara pengujian UU Nomor 42 Tahun 2008 Tentang Pemilihan Umum Presiden dan Wakil Presiden merupakan putusan final. Pelaksanaan putusan MK ini tentunyamembawa implikasi dan tantangan besar bagi bangsa Indonesia dalam perbaikan sistem politik dan demokrasi yang lebih matang. Efektivitas pemilu serentak 2019 masih menjadi perdebatan publik, UU Pemilu yang baru disahkan sebagai payung hukum Pemilu 2019 masih dalam proses uji materi di Mahkamah Konstitusi.Secara teoritikpemilu serentak 2019 sangat memungkinkan untuk dilaksanakan apalagi jika melihat dinamika politik Indonesia yang semakin baik sejak era reformasi. Hal utama yang harus menjadi kesepakatan bersama adalah sistem pemilu hanyalah sebuah instrumen dalam sistem demokrasi, instrumen ini tentunya dapat disesuaikan dan diubah tergantung dengan kondisi dan tujuan suatu negara. Pemilu 2019 akan menjadi indikator dalam sistem demokrasi langsung dimana orang dapat berpartisipasi dalam pilihan politik mereka.
\end{abstract}

Kata kunci: Pemilu serentak, UU pemilu, partisipasi masyarakat.

\section{MEASURING THE EFFECTIVENESS OF SIMULTANEOUS ELECTIONS 2019}

\begin{abstract}
The idea of holding elections simultaneously 2019 brings political consequences nationally and regionally. Decision of the Constitutional Court (MK) No. 14/PUU-XI/2013 on the case of review of law No. 42 Year 2008 regarding the General Election of President and Vice President is the final decision. The implementation of the Constitutional Court's decision certainly brings great implications and challenges for Indonesia as a nationin improving the more mature political and democratic system. The effectiveness of 2019 general election is still a public debate, the election law as the basis of its legal umbrella is still in judicial review process in the Constitutional Court. Theoretically, the 2019 election is feasibleto be implemented, consideringIndonesia's political dynamics getting better since the reform era. The main thing that should be commonly agreed is the electoral system is just an instrument in a democratic system, this instrument can certainly be adjusted and changed depending on the conditions and goals of a country. The 2019 election will be an indicator in a direct democratic system in which people can participate in their political choices.
\end{abstract}

Key words: Simultaneous elections, election law, community participation.

\section{PENDAHULUAN}

Pelaksanaan pemilihan umum (Pemilu) menjadi indikator dalam sistem demokrasi karena rakyat dapat berpartisipasi dalam menentukan pilihan politiknya terhadap pemerintahan dan negaranya. Melalui pemilu rakyat bisa memilih para wakilnya untuk duduk dalam parlemen maupun struktur pemerintahan. Dalam sejarah perjalanan bangsa Indonesia pemilu menjadi upaya nyata dalam mewujudkan tegaknya demokrasi dan merealisasikan kedaulatan rakyat dengan prinsip jujur dan adil (jurdil) serta langsung, umum, bebas dan rahasia (luber).Pemilu juga menjadi sarana lima tahunan pergantian kekuasaan dan kepemimpinan nasional, dimana partai politik dapat saling berkompetisi untuk mendapatkan simpati rakyat dalam memperoleh kekuasaan politik (legislatif, eksekutif) yang legitimasinya sah secara undang-undang dan konstitusional.

Sebagaipemegangkedaulatan,makarakyat yang menentukan corak dan cara serta tujuan apa yang hendak dicapai dalam kehidupan kenegaraan. Hal ini menunjukkan bahwarakyat berkuasa secara independen atas dirinya sendiri (Nurtjahjo, 2006). Selain itu, pentingnya pemilu dalam negara demokrasi senada dengan tujuan penyelenggaraan pemilihan umum itu sendiri, yaitu membuka peluang untuk terjadinya pergantian pemerintahan sekaligus momentum untuk menguji dan mengevaluasi kualitas dan kuantitas dukungan rakyat terhadap keberhasilan dan kekurangan pemerintah yang sedangberkuasa (Bisariyadi, et.al., 2012). 
Pemilu sering disebut sebagai ajang pesta demokrasi rakyat yang menjadi cerminan ikut andilnya rakyat dalam menentukan pemimpin dan arah perkembangan bangsa. Namun dalam perkembangannya pemilu di Indonesia masih banyak kekurangan dan menjadi pekerjaan rumah yang perlu diperbaiki bersama oleh seluruh elemen bangsa.Perubahan model sistem pemilu dari pemilu ke pemilu berikutnya tentu menjadi halyang dibutuhkan, hal ini dikarenakan perkembangan dan situasi perpolitikan bangsa Indonesia yang terus berubah. Masih banyak sebagian masyarakat yang menilai bahwa selama ini pemilu hanya sebagai agenda rutinitas lima tahunan yang menghabiskan uang rakyat, sementara hasil dari pelaksanaan pemilu itu sendiri belum mampu menciptakan masyarakat yang adil dan sejahtera. Anggapan seperti ini tentunya menjadi masukan bagi penyelenggara pemilu untuk lebih baik dalam melaksanakan agenda pemilu di masa yang akan datang.

Pasca Putusan Mahkamah Konstitusi No. 14/PUU-XI/2013 yang mengabulkan sebagian permohonan uji materi (judicial review) Undang-Undang Nomor 42 Tahun 2008 Tentang Pemilihan Umum Presiden dan Wakil Presiden yang diajukan Effendi Gazali dkk aturan pemilu serentak ini muncul, keluarnya putusan MK ini merupakan salah satu terobosan hukum baru. Dimana dalam amar putusannya MK menyatakan: Pasal 3 Ayat (5), Pasal 12 Ayat (1) dan Ayat (2), Pasal 14 Ayat (2), dan Pasal 112 Undang-Undang Nomor 42 Tahun 2008 tidak mempunyai kekuatan hukum mengikat (inkonstitusional). Dari rangkaian ketentuan yang dinyatakan kehilangan validitas konstitusional tersebut, MK menegaskan, pemilihan umum presiden dan wakil presiden harus dilaksanakan serentak dengan pemilihan umum anggota DPR, DPD, dan DPRD. Dengan putusan ini, ketentuan bahwa Pemilihan Umum Presiden dan Wakil Presiden (Pemilu Presiden) dilaksanakan setelahPemilihan Umum anggota DPR, DPD, dan DPRD (Pemilu Legislatif) adalah inkonstitusional, dalam diktum kedua dari amar putusan Mahkamah Konstitusi menegaskan bahwa putusan pemilu serentak akan diterapkan pada pemilu 2019.

Putusan MK merupakan putusan final, bagian yang menarik dari amar putusan MK tersebut adalah pelaksanaannya baru bisa dilaksanakan pada pemilu 2019 mengingat pelaksanaan persiapan pemilu 2014 waktu itu sudah mulai berjalan. Apabila pemilu serentak 2019 dapat dilaksanakan maka akan menjadi sejarah Indonesia untuk pertama kalinya pemilu dilaksanakan secara bersamaan.Rancangan UU Pemilu 2019 telah disahkan oleh DPR dan Pemerintah, banyak kalangan yang merasa kurang puas dengan isi undang-undang tersebut kemudian mengajukan uji materi ke MK. Sedikitnya ada lima isu-isu krusial dalam UU Pemilu yang menjadi perdebatan elit politik pada saat paripurna di DPR yaitu: ambang batas presidential (presidential threshold), ambang batas parlemen (parliamentary threshold), alokasi kursi anggota DPR per daerah pemilihan (dapil), metode konversi suara pemilu legislatif, dan sistem pemilu.

Ketika MK kemudian memutuskan untuk penyelenggaraan pemilu serentak, putusan MK masih belum putusan operasional yang menjawab kerisauan-kerisauan atas banyaknya penyelenggaraan pemilu di atas. Mungkin alasan agar tidak jenuh, bisa terjawab oleh pemilu serentak ini, juga mungkin soal efisiensi dalam penyelenggaraan. Terlepas dari itu, penyelenggaraan pemilu serentak tahun 2019 sesuai putusan MK masih belum mengatur operasionalisasi yang bisa memperkuat sistem presidensial, karena pemilu serentak putusan MK adalah pemilu yang lebih tepatnya diserentakkan, 5 kotak suara. Ini yang kemudian tidak mengakibatkan munculnya coattail effect (Nuryanti, 2015). Menurut Madariaga, coattail effect ini secara teori sebenarnya mengatur hubungansequential dimana partai yang menjadi pemenang pada pemilu legislatif adalah partai dimana presiden dan wakil presiden terpilih berasal (Madariaga et.al., dalam Nuryanti, 2015).

Dari berbagai persoalan diatas,pemilu serentak 2019 tentu menjadi tantangan dan peluang bagi seluruh elemen bangsa dalam perbaikan sistem politik dan demokrasi di Indonesia. Agar pemilu serentak 2019 dapat terlaksana dengan baik diperlukan kesungguhan dari pemerintah dan anggota parlemen untuk tidak terjebak dalam permainan politik yang oportunis dan pragmatis,penyelenggaraan pemilu serentak 2019 harus menjadi referensi sistem pemilu baru di Indonesia. Tulisan ini dibuat sebagai upaya melihat aspek-aspek apa yang perlu dilakukan dalam suksesi pelaksanaan pemilu serentak 2019. 


\section{METODE}

Data-data serta argumentasi yang dibangun dalam tulisan inimenggunakan studi kualitatif,yakni dengan mengumpulkan berbagai sumber referensi ilmiah dari sumber primer dan sumber sekunder melalui pene-lusuran tulisan terkait seperti jurnal, paper, dan berita media massa tentang dinamika dan fenomena pemilu serentak di Indonesia khususnya terkait dengan pemilu serentak 2019. Tujuan lain dalam penggunaan desain kualitatif ini adalah untuk memahami kerangka analisis berdasarkanrealita yang terjadi tentang esensi pemilu serentak di Indonesia. Analisis data dilakukan dengan analisis deskriptif dengan menelaah dinamika tentang pemilu serentak di Indonesia khususnya setelah keluarnya putusan MK Nomor 14/PUU$\mathrm{XI} / 2013$ tentang pemilihan umum presiden dan wakil presiden harus dilaksanakan serentak dengan pemilihan umum anggota DPR, DPD, dan DPRD pada tahun2019 sertadisahkannya UU Pemilu sebagai upaya dalam memberikan kesimpulan tentang suatu pemikiran yang rasional dan argumentatif dalam memilah fakta dan konsep yang ada.

\section{HASIL DAN PEMBAHASAN}

\section{Penguatan Sistem Presidensial melalui Pemilu Serentak}

Demokrasi dan pemilu seperti dua sisi mata uang yang erat keberadaannya, pelaksanaan pemilu yang menjadi hajat rakyat menjadi ciri masih tegaknya sistem demokrasi dalam suatu negara. Prinsip demokrasi dari rakyat, oleh rakyat, dan untuk rakyat dapat dilihat dalam kegiatan pemilihan umum. Prosesi pemilihan umum sebagai salah satu perwujudan sarana kehidupan politik bagi warga negara yang menjadi pilar kedua sistem demokrasi yang disebutkan dalam buku Robert Dahl, Polyarchy: Participation and Oposition (dalam Surbakti, et.al., 2011).

Rakyat sebagai pemilik kedaulatan tertinggi memiliki hak sebagai warga negara untuk menyalurkan hak-hak politiknya melalui pemilu, peran dan partisipasi rakyat ini menjadi bukti bahwa nilai-nilai demokrasi masih berjalan dengan baik.Jika tidak ada pemilu maka rakyat tidak berdaulat,karena dengan pemilu, rakyat dapat menentukan siapa yang menjadi wakil-wakil dan pemimpinnya di kursi pemerintahan sehingga mereka dapat menjadi operator negara dalam menggapai harapan rakyat. Dalam pelaksanaannya, pemilu sangat bergantung pada pengadopsian sistem pemerintahan yang dianut oleh suatu negara, karena akan mempengaruhi model pelaksanaan kegiatan pemilu. Sistem pemerintahan yang dimaksud di sini adalahberkaitan dengan pengertian regeringsdaad, yaitu penyelenggaraan pemerintahan oleh eksekutif dalam hubungannya dengan kekuasaan legislatif (Asshiddiqie, 2007).

Dalam konteks Indonesia,sistem presidensial dan sistem multipartai diterapkan secara bersama-sama. Implikasi dari kombinasi pemilihan sistem ini secara bersamaan adalah potensi adanya pelemahan terhadap sistem presidensial itu sendiri sehingga berujung pada pemerintahan yang tidak stabil. Sejak era reformasi 1998 pemerintah dalam hal ini presiden Indonesia terpilihterkadang terjebak dalam konflik kepentingan pada saat akan membentuk kabinet dan memutuskan suatu kebijakan politik, tuntutan dari partaipartai pendukung serta kepentingan politik di parlemen terkadang membuat pemerintahan berjalan kurang efektif karena tersandera oleh kepentingan politik yang bersifat oportunis dan pragmatis.

Dalamperkembanganpemiludi Indonesia, secara tidak langsung upaya penguatan terhadap sistem presidensial mulai berjalan sejak era reformasi 1998. Kultur politik yang berubah seiring dengan perkembangan dan tuntutan global menjadikan Indonesia terus berbenah diri dalam perbaikan sistem politik dan tata kenegaraan. Majelis Permusyawaratan Rakyat pun sepakat bahwadengan adanya amandemen UUD 1945 maka akan memberikan pengaruh terhadap tata cara pemilihan Presiden dan Wakil Presiden. Asshiddiqie (2010) menyebutkan bahwa dalam pelaksanaan sistem presidensial, Presiden bertanggungjawab kepada rakyat secara langsung dan bukan melalui MPR.

Jika merujuk sejarah, perubahan ini mulai terlihat dari transformasi pemilihan presiden dan wakil presiden oleh MPR menjadi pemilihan presiden dan wakil presiden secara langsung oleh rakyat pada pemilu 2004.Dimana Susilo Bambang Yudhoyono dan Jusuf Kalla terpilih sebagai presiden dan wakil presiden melalui pemilu langsung oleh rakyat. Namun, realita yang terjadi bahwa walaupun presiden dan wakil 
presiden dipilih secara langsung oleh rakyat melalui partai politik pengusungnya kerap terjadi intervensi politik dalam penyusunan anggota kabinet dan kebijakan politiknya. Yuda (2010) menyebutkan sejak masa pemerintahan Presiden Susilo Bambang Yudhoyono dan Wakil Presiden Jusuf Kalla, hingga masa Presiden Joko Widodo dan Wakil Presiden Jusuf Kalla saat ini.

Adanya intervensi politik tersebut berakibatpada kurang optimalnyakinerja eksekutif, presiden dalam hal ini sebagai kepala eksekutif sering tersandera oleh partai pendukungnya. Presiden sering terlihat lemah dan lamban dalam mensikapi isu-isu publik, hal ini yang terkadang membuat rakyat merasa kecewa dengan kinerja pemerintah. Sistem pemilu proporsional yang dipilih Indonesia bersamaan dengan penerapan sistem presidensial berbasis sistem multipartai dirasa banyak kalangan tidak mencerminkan sistem yang ideal. Hal ini dikarenakan adanya kerancuan dan tumpang tindih kepentingan politik pasca pemilu, reaksi masyarakat terhadap pemerintah yang terbagi-bagi, terpecah (divided government) dan ketidakberdayaan pemerintah dalam menghadapi oposisi di parlemen. Hal ini berakibat kepentingan masyarakat sering terabaikan.

Dalam melihat kombinasi dua sistem yang berbeda, setidaknya ada tiga alasan mengapa kombinasi sistem presidensial dan sistem multi-partai cenderung bermasalah, yaitu: (1) Sistem presidensial berbasis multipartai cenderung mengakibatkan kebuntuan hubungan eksekutif dan legislatif sehingga kerja pemerintahan menjadi tidak efektif; (2) Sistem multipartai cenderung menciptakan polarisasi ideologis daripada sistem duapartai; (3) Kombinasi kedua sistem tersebut juga berimplikasi pada sulitnya membentuk koalisi antarpartai dalam sistem presidensial; Permasalahan yang terjadi dalam penentuan koalisi pilpres untuk mengusung calon presiden dan wakil presiden ada pasca penetapan kursi legislatif yang fragmentatif. Lobi politik terjadi dimana-mana, sifat pragmatis, dan singkat menjadi kerikil tajam yang juga kerap terjadi dimanapun, termasuk di Indonesia. Akibatnya, pemerintah yang terpilih menjadi tersandera baik oleh kekuatan pendukungnya sendiri dan juga oleh pihak oposisi (Haris, et.al., 2015).

Pascakeluarnya putusan MK yaitu dengan dibatalkannya Pasal 3 ayat (5) Undang-Undang Nomor 42 Tahun 2008 Tentang Pemilihan Umum Presiden dan Wakil Presiden, MK memerintahkan mulai tahun 2019 pemilihan umum presiden diselenggarakan secara serentak dengan pemilihan umum legislatif. Syamsuddin Haris et.al. menyebutkan dengan adanya putusan ini tentu pemilu serentak antara presiden dan legislatif tidak hanya bertujuan untuk tercapainya efisensi anggaran dan waktu, tetapi juga berimplikasi pada perubahan sistem tata ketatanegaraan di Indonesia yaitu: Pertama, peningkatan efektifitas pemerintahan karena diasumsikan pemerintahan yang dihasilkan melalui keserentakan pemilu presiden dan pemilu legislatif lebih stabil sebagai akibat coattail effect, yakni keterpilihan calon presiden yang dari parpol atau koalisi parpol tertentu akan mempengaruhi keterpilihan anggota legislatif dari parpol atau koalisi parpol tertentu pula. Dengan demikian konflik eksekutiflegislatif, instabilitas, dan bahkan jalan buntu politik sebagai komplikasi skema sistem presidensial berbasis sistem multipartai seperti kekhawatiran Juan Linz dan Scott Mainwaring diharapkan tidak menjadi kenyataan. Itu artinya, penyelenggaraan pemilu serentak berpotensi memperbesar dukungan politik DPR terhadap presiden terpilih (Haris, et.al., 2015).

Kedua, pembentukan koalisi politik yang mau tidak mau harus dilakukan sebelum pemilu legislatif diharapkan dapat memaksaparpol mengubah orientasi koalisi dari yang bersifat jangka pendek dan cenderung oportunistik menjadi koalisi berbasis kesamaan ideologi, visi, dan platform politik. Efek berikutnya dari koalisi berbasis kesamaan ideologi ini adalah tegaknya disiplin parpol, sehingga orientasi para politisi parpol pun diharapkan bisa berubah dari perburuan kekuasaan (officeseeking) menjadi perjuangan mewujudkan kebijakan (policy-seeking). Ketiga, pemisahan pemilu nasional serentak dan pemilu lokal serentak diharapkan berdampak positif pada tiga hal: (1) ada jeda waktu bagi rakyat menilai kinerja pemerintahan hasil pemilu serentak nasional; (2) terbuka peluang yang besar bagi terangkatnya isu lokal ke tingkat nasional yang selama ini cenderung tenggelamoleh isu nasional; (3) semakin besarnya peluang elite politik lokal yang kepemimpinannya berhasil untuk bersaing menjadi elite politik di tingkat nasional(Haris, et.al., 2015). 
Keempat, secara tidak langsung diharapkan terjadi penyederhanaan sistem kepartaian menuju sistem multipartai sederhana (moderat). Sebagai akibat terpilihnya parpol atau gabungan parpol yang sama dalam pemilu presiden dan pemilu DPR, fragmentasi parpol di parlemen berkurang dan pada akhirnya diharapkan berujung pada terbentuknya sistem multipartai moderat. Kelima, pemilu serentak nasional yang terpisah dari pemilu serentak lokal diharapkan dapat mengurangi potensi politik transaksional sebagai akibat melembaganya oportunisme politik seperti yang berlangsung selama ini. Transaksi atas dasar kepentingan jangka pendek bisa dikurangi jika fondasi koalisi politik berbasiskan kesamaan visi dan platform politik. Keenam, pemilu serentak nasional yang dipisahkan dari pemilu serentak lokal diharapkan dapat meningkatkan kualitas hasil pilihan masyarakat karena perhatian pemilih tidak harus terpecah pada pilihan yang terlampau banyak sekaligus di saat yang sangat terbatas dalam bilik suara (Haris, et.al., 2015).

Berdasarkan penyelenggaraan pilpres 2004, 2009, dan 2014 yang dilakukan setelah pemilu legislatif, ditemukan fakta politik bahwa presiden terpaksa harus melakukan negosiasi dan tawar-menawar politik terlebih dahulu dengan parpol, sebagai bagian dari konsekuensi logis dukungan demi terpilihnya sebagai presiden dan dukungan DPR dalam penyelenggaraan pemerintahan. Hal itu tentu berakibat akan sangat mempengaruhi jalannya roda pemerintahan di kemudian hari. Belum lagi negosiasi dan tawar-menawar tersebut pada kenyataannya lebih banyak bersifat taktis dan sesaat ketimbang bersifat strategis dan jangka panjang. Maka itu, presiden faktanya menjadi sangat tergantung parpol yang menurut MK dapat mereduksi posisi presiden dalam menjalankan kekuasaan pemerintahan menurut sistem pemerintahan presidensial (Haris, et.al., 2015). Pertimbangan MK inilah yang menjadi titik tolak pentingnya pemilu serentak diproyeksikan dapat memperkuat sistem presidensial.

Penerapan sistem presidensial yang dikombinasikan dengan sistem multipartai berimplikasi pada minimnya dukungan yang diperoleh presiden di parlemen. Oleh karenanya koalisi antar partai dilakukan sebagai upaya mendapatkan dukungan di parlemen. Menurut Giovanni (dalam Isra, 2009) mengemukakan bahwa presiden tetap memerlukan dukungan legislatifsebab tanpa dukungan tersebut presiden akan menghadapi situasi sulit yang mengancam stabilitas pemerintahan, kecenderungan yang muncul adalah lahirnya konflik kepentingan antara presiden dengan parlemen. Padahal untuk untuk menjaga stabilitas pemerintahan dalam struktur politik presidensial idealnya partai pendukung presiden adalah partai mayoritas, yaitu partai yang didukung suara mayoritas di parlemen. Tujuannya adalah untuk menjaga stabilitas pemerintahan presiden terpilih agara presiden mudah mendapatkan dukungan secara politik dari parlemen guna melancarkan kebijakan politik yang dibuat presiden (Yuda, 2010).

Pemerintahan dengan sistem presidensial adalah suatu sistem pemerintahan dimana kedudukan eksekutif tidak bertanggungjawab kepada badan perwakilan rakyat, dengan kata lain kekuasaan eksekutif berada di luar pengawasan (langsung) parlemen (Tutik, 2010).Dalam tipe ini menurut Mahfud (2010) menyebutkan bahwa kedudukan eksekutif tidak tergantung kepada badan perwakilan rakyat, adapun dasar hukum kekuasaan eksekutif dikembalikan kepada pemilihan rakyat.Dalam upaya penguatan sistem presidensial Mark P. Jones (dalam Hanan, 2015) mengungkapkan ".... all evidences indicate the functioning of presidential system is greatly enhanced when the president is providing with a majority or nearmajority in the legislature". Dengan demikian bahwa sistem presidensial tergantung pada dukungan politik yang ada di lembaga legislatif bagi seorang presiden. Pemilu serentak menjadi salah satu upaya dalam memperkuat sistem pemerintahan presidensial.

\section{Suksesi Pemilu Serentak 2019}

Dalam upaya mensukseskan hajat bangsa untukterselenggaranya pemilu serentak tahun 2019, diperlukan kerjasama dan sinergitas semua pihak untuk ikut mensukseskannya. Setidaknya ada 5 (lima) aspek yang perlu dilakukan dalam upaya suksesi pemilu serentak 2019 yaitu:Pertama, perlunya undang-undang yang aspiratif dan aplikatif sebagai payung hukum serta desain model pemilu serentak 2019.Jika merujuk pada sejarah perundangundangan sebelum era reformasi 1998, hampir lebih dari tiga puluh tahun dimasa Orde Baru perpolitikan bangsa mencermikan demokrasi 
yang kurang sehat, praktek demokrasi di Indonesia terbelenggu tanpa adanya kebebasan mengemukakan hak dan pendapat dimuka umum.

Hukum yang konservatif memiliki beberapa karakteristik antara lain: (1) Proses pembuatannya sentralistik (tidak partisipatif) karena didominasi oleh lembaga-lembaga negara yang dibentuk secara tidak demokrastis pula oleh negara. Di sini peran lembaga peradilan dan kekuatan-kekuatan masyarakat sangat sumir; (2) Isinya bersifat positivistinstrumentalistik (tidak aspiratif) dalam arti lebih mencerminkan kehendak penguasa karena sejak semula hukum telah dijadikan alat (instrumen) pembenar yang akan maupun (terlanjur) dilakukan oleh pemegang kekuasaan yang dominan; (3) Lingkup isinya bersifat open responsive (tidak responsif) sehingga mudah ditafsir secara sepihak dan dipaksakan penerimanya oleh pemegang kekuasaan negara; (4) Pelaksanaannya lebih mengutamakan program dan kebijakan sektoral jangka pendek daripada menegakkan aturan-aturan hukum yang resmi berlaku; (5) Penegakannya lebih mengutamakan perlindungan korp sehingga tidak jarang pembelokan kasus hukum oleh aparat dengan mengaburkan kasus pelanggaran menjadi kasus prosedur atau menampilkan kambang hitam sebagai pelaku yang harus dihukum (Mahfud, 2004).

Karakteristik hukum konservatif tersebut di atas menjadi tidak relevan dalam konteks saat ini, era reformasi menuntut hukum dan perundangan yang dibuat harus lebih aspiratif, responsif, dan aplikatif untuk kepentingan bangsa dan negara. Formulasi perundang-undangan harus mampu menampung aspirasi pemikiran lapisan masyarakat dan karakteristik bangsa Indonesia sehingga produk hukum yang dihasilkan dapat diterima oleh seluruh lapisan masyarakat. Dengan disahkannya UU Pemilu 2019 tentu masyarakat berharap bahwa Pemilu 2019 dapat menjadi lebih baik lagi dibandingkan dengan model dan sistem pemilu sebelumnya. UU Pemiluharus menjadi semangat bersama dalam membenahi sistem pemilu di Indonesia sehingga mutu demokrasi di Indonesia semakin baik.

UU Pemilu 2019 telah disahkan dengan pilihan opsi A yang berisi: (a) Presidential Threshold sebesar 20-25 persen, aturan ini mensyaratkan partai politik atau gabungan parpol harus memiliki 20 persen jumlah kursi di DPR dan/atau 25 persen suara sah nasional di pemilu sebelumnya untuk pengajuan calon presiden dan wakil presiden. (b) Parliamentary Threshold sebesar 4 persen menjadi prasyarat parpol untuk kader/wakilnya dapat duduk sebagai anggota dewan. (c) Sistem Pemilu yang dipilih dalam pemilu 2019 adaalah sistem proporsional terbuka. (d) Dapil Magnitude 3-10, yaitu alokasi daerah pemilihan yakni rentang jumlah kursi anggota DPR di setiap daerah pemilihan. Berdasarkan Pasal 22 ayat (2) UU Nomor 8/2012 disebutkan jumlah kursi di setiap dapil anggota DPR paling sedikit 3 kursi dan paling banyak 10 kursi. (e) Metode konversi suara model Sainte Lague murni, metode sainte lague ini dalam melakukan penghitungan suara bersifat proporsional yaitu tidakadapembedaan dantidakmemihak apakah itu partai kecil ataupun partai besar. Metode konversi suara ini mempengaruhi jumlah kursi setiap parpol yang lolos ke DPR. Metode sainte lague murni menerapkan bilangan pembagi suara berangka ganjil seperti, 1, 3, 5, 7, 9, dan seterusnya. Metode sainte lague ini dalam melakukan penghitungan suara bersifat proporsional yaitu tidak ada pembedaan dan tidak memihak apakah itu partai kecil ataupun partai besar (Detik.com, 2017).

Kedua, perlunya penyelenggara pemilu yang kapabel dan profesional.Secara khusus komisioner KPU periode 2017-2022 memiliki tanggungjawab lebih berat dalam menjalankan tugasnya, mereka akan mengambil alih proses pelaksanaan pilkada serentak tahun 2018 yang saat ini sudah dipersiapkan oleh komisioner KPU sebelumnya. Tugas berat lainnya adalah melakukan perencanaan pelaksanaan pemilu serentak 2019 yang belum pernah ada contohnya di negeri ini, hal ini tentu memerlukan konsolidasi dan kekompakan internal KPU dalammelakukan manajerial pemilu mendatang. KPU sebagai lembaga resmi penyelenggara pemilu memiliki tanggungjawab besar dalam melaksanakan pemiluyang profesional, mandiri, berintegrasi dan bebas dari kepentingan politik. Komisioner KPU tidak hanya dituntut cakap dan kapabel dalam menjalankan tanggungjawab menyelenggarakanpemilu, tapi juga tuntutan netralitas dari sikap dan pandangan politiknya.

Dalam catatan Perludem hal lain yang perlu dilakukan dalam penyelenggaraan pemilu adalah perlunya penguatan Bawaslu sebagai suatu badan pengawas pemilu, yakni dengan 
memberikan kewenangan quasiyudisial. Yaitu, berupa fungsi ajudikasi (perwasitan), sehingga Bawaslu bisa memutus pelanggaran dan sengketa pemilu(Husein, 2014). Posisi Bawaslu yang saat ini terkesan hanya sebagai pengawas pemilu saja perlu diberikan kewenangan yang lebih besar terutama dalam mensikapi dan menindak sengketa yang muncul dalam pemilu.

Ketiga, perlunya uji publik efektivitas pembiayaan pemilu serentak. Jika melihat pada data Bappenas penyelenggaraan pemilu 2009 yang mencapai 8,5 triliun dan mengalami kenaikan biaya pada pemilu 2014 yang mencapai 16 triliun (Antara, 2017). Maka secara logika pelaksanaan pemilu serentak 2019 seyogyanya membutuhkan biaya yang lebih murah dan minim. Hal ini dikarenakan model pemilu 2019 akan berbeda dengan skema model pemilu sebelumnya. Penyelenggaraan Pemilu legislatif dan Presiden dan Wakil Presiden tahun 2009 dan 2014 dilakukan secara terpisah, sedangkan rencana pelaksanaan pemilu 2019 akan dilakukan secara serentak dalam hari yang sama untuk memilih anggota legislatif,serta memilih presiden dan wakil presiden.

Biaya penyelenggaraan pemilu 2019 yang berasal dari APBN harus benar-benar dibuat lebih efisien dan efektif. Penyelenggaraan pemilu yang bersih, transparan dan akuntabel dalam pengelolaan uang negara akan meningkatkan kepercayaan masyarakat kepada negara. Penyelenggara pemilu dapat melakukan efisiensi anggaran terutama dalam penyediaan logistik pemilu dan sosialisasi pemilu. Dalam hal efisiensi logistik KPU dapat menggunakan kotak pemungutan suara, tinta dan alat pencoblos ekspilkada serentak 2018 sedangkan untuk pelaksanaan sosialisasi pemilu, KPU dapat bekerjasama dengan lembaga pendidikan seperti sekolah, kampus, dan pondok pesantren.

Berdasarkan riset Indonesia Budget Center (IBC) untuk Pemilu tahun 2004 dan 2009 beberapa titik yang rawan dalam pengelolaan anggaran pemilu adalah terkait dengan urusan logistik yaitu: lelang kotak suara, lelang kertas suara, sistem distribusi logistik, dan lelang tinta (Gresnews.com, 2014). Lemahnya pengawasan anggaran pemilu juga sering terjadi pada anggaran pengamanan dan pengawasan serta adanya rangkap anggaran sosialisasi pemilu antar satu kementerian dengan kementerian lainnya. Dengan dilakukannya proses sosialisasi kepada masyarakat sejak pembuatan rencana anggaran biaya pemilu maka masyarakat akanlebih tahu dan ikut berpartisipasi dalam proses efektivitas pembiayaan pemilu.

Keempat, perlunya kesiapanpartai politik dalam pemilu serentak. Diperlukan kesiapan dalam manajerial organisasi di internal partai politik sehingga bisa ikut menjadi peserta pemilu serentak 2019 serta kesiapan manajerial eksternal partai politik dalam membangun komunikasi politik dengan partai politik lainnya serta dengan masyarakat. Dalam perkembangan sistem politik Indonesia telah menempatkan partai politik sebagai pilar utama penyangga jalannya demokrasi, keberadaan partai politik menjadi ciri bahwa demokrasi masih berjalan dengan baik di Indonesia. Dalam UU Nomor 2 Tahun 2011 Tentang Partai Politik disebutkan bahwa "Partai Politik adalah organisasi yang bersifat nasional dan dibentuk oleh sekelompok warga negara Indonesia secara sukarela atas dasar kesamaan kehendak dan cita-cita untuk memperjuangkan dan membela kepentingan politik anggota, masyarakat, bangsa dan negara, serta memelihara keutuhan Negara Kesatuan Republik Indonesia berdasarkan Pancasila dan Undang-Undang Dasar Negara Republik Indonesia Tahun 1945". Substansinya adalah partai politik dapat ikut berperan aktif dalam menegakan demokrasi dan kesatuan NKRI. Diantara peran partai politik adalah dengan memberikan pendidikan politik yang berkarakter kebangsaan kepada masyarakat. Pendidikan politik ini menjadi penting sebagai sarana partai politik dalam upaya mencerdaskan kehidupan bangsa.

Pemilu serentak 2019 akan memberikan implikasi pada sistem penyelenggaraan pemilu. KPU berupaya melakukan sistem digitaliasi dalamproses validasi partai peserta pemilu. Salah satu upaya KPU adalah dengan menerapkan aturan baru bahwa seluruh partai politik peserta pemilu wajib mengikuti Sistem Informasi Partai Politik (Sipol) secara online. Sistem ini menjadi penting karena parpol bisa menginput berbagai data parpol yang menjadi bahan verifikasi sebagai peserta pemilu, seperti jumlah anggota, visi-misi, dan berkas administrasi lainnya. Adanya perubahan sistem ini tentu menjadi tantangan bagi partai politik untuk lebih siap dan memperbaiki manajerial administrasi organisasi partainya.

Kelima, perlunya sosialisasi politik dan partisipasi masyarakat. Dalam upaya suksesi 
pelaksanaan pemilu serentak 2019, masyarakat menjadi obyek penting dalam suksesnya pelaksanaan pemilu serentak. Masyarakat sebagai pemberi mandat memiliki hak untuk tahu tentang sistem pemilu serentak. Maka menjadi penting adalah tentang kesiapan masyarakat dalam pemilu serentak 2019. Menurut Pahlevi et.al. (2015) kesiapan yang dimaksud adalah kesadaran politik yang lebih baik serta tingkat partisipasi masyarakat dalam penyelenggaraan pemilu. Jika dikatakan bahwa masyarakat sekarang sudah pintar tetapi dimaknai bahwa siapa saja yang memberikan iming-iming akan diterima tetapi ketika memilih adalah urusan pribadi, harus diubah bahwa kesadaran politik itu benar-benar dimulai sejak awal tahapan pemilihan hingga akhir pada saat memilih bahwa tidak ada istilah menolerir money politic dalam bentuk apapun. Penting kiranya sejak awal membangun kesadaran politik masyarakat dalam melahirkan pemilu yang bersih dan jurdil, adanya sosialisasi politik yang terencana dan terprogram secara kontinuakanmeningkatkan partisipasi politik masyarakat untuk ambil bagian dalam suksesi pemilu serentak 2019.

\section{SIMPULAN}

Pelaksanaan pemilu serentak 2019 masih sekitar dua tahun lagi. Namun masih banyak persoalan pemilu serentak yang belum terselesaikan, banyaknya persoalan yang harus diselesaikan membutuhkan kesolidan dan sinergitas dari seluruh anak bangsa. Bagaimana konsep dan model pemilu serentak 2019 yang paling efektif untuk dilaksanakan serta bagaimana kesiapan dari penyelenggaraan pemilu menjadi persoalan utama yang harus dicari solusinya. Undangundang Pemilu 2019 yang telah disahkan bersama antara DPR dan Pemerintah menjadi pertaruhan sinergitas eksekutif dan legislatif dalam meningkatkan mutu dan kualitas sistem pemilu di Indonesia. Apapun hasil keputusan MK terkait UU Pemilu yang saat ini masih dalam proses uji materi harus diterima dengan legowo oleh semua pihak dalam menjaga keamanan dan suksesnya Pemilu serentak 2019. Efektivitas pemilu serentak 2019 dapat dilaksanakan dengan baik setidaknya dengan memperkuat 5 aspek utama yaitu: UU Pemilu yang aspiratif dan aplikatif sebagai payung hukum serta desain model pemilu serentak
2019, penyelenggara pemilu yang kapabel dan profesional, efektivitas pembiayaan pemilu serentak yang lebih pro rakyat, kesiapan partai politik dalam pemilu serentak, dan perlunya sosialisasi politik dan partisipasi masyarakat. Secara teoritik pemilu serentak 2019 sangat memungkinkan untuk dilaksanakan dalam satu hari dan pada hari yang sama yakni untuk pemilu legislatif anggota DPR, DPD, DPRD, dan pemilu presiden dan wakil presiden. Namun, yang perlu menjadi kesepakatan bersama adalah pemilu hanya sebuah instrumen dalam sistem demokrasi, instrumen ini tentunya dapat disesuaikan dan diubah tergantung dengan kondisional dan tujuan suatu negara. Hal yang perlu dijunjung tinggi bersama adalah kepentingan bangsa dan NKRI harus menjadi tujuan dan prioritas yang paling utama.

\section{DAFTAR PUSTAKA}

Antaranews.com. (2013, Maret 15). Rp 16 Triliun Biaya Pemilu 2014. Retrieved Juli 22, 2017, from https://www. antaranews.com/berita/363483/rp16triliun-biaya-pemilu2014

Asshiddiqie, J. (2007). Pokok-Pokok Hukum Tata Negara Indonesia Pasca Reformasi. Jakarta: Buana Ilmu Populer.

(2010). Konstitusi dan Konstitusionalisme Indonesia. Jakarta: Sinar Grafika.

Bisariyadi, (2012). "Komparasi Mekanisme Penyelesaian Sengketa Pemilu di Beberapa Negara Penganut Paham Demokrasi Konstitusional. Jurnal Konstitusi. 9 (3).

Gressnews.com. (2014, Januari 24). Lima Titik Rawan Korupsi Dana Pemilu 2014. Retrieved April 1, 2017, from http://www.gresnews.com/Berita/ Politik/1830241-Lima-Titik-RawanKorupsi-Dana-Pemilu 2014/0/

Hanan, D. (2015). "Memperkuat Presidensialisme Multipartai di Indonesia: Pemilu sentak,SistemPemilu,danSistemKepartaian".http://www.puskapol. ui.ac.id/wpcontent/uploads/2015/02/ Makalah Djayadi-Hanan.pdf 
Haris, S. (2015). Position Paper: Pemilu Nasional Serentak 2019. Jakarta: Electoral Research Institute. Lembaga Ilmu Pengetahuan Indonesia.

Husein, H. (2014). Pemilu Indonesia: Fakta, Angka, Analisis, dan Studi Banding. Jakarta: Perludem.

Isra, S. (2009). "Pemilihan Presiden Langsung dan Problematika Koalisi dalam Sistem Presidensial". Jurnal Konstitusi, II, No. 1. Juni 2009.

MD, M. M. (2004). "Langkah Politik dan Bingkai Paradikmatik dalam Penegakan HukumKita". Makalah.BahanKumpulan Perkuliahan Pasca Sarjana FH UI. (2010). Membangun Politik Hukum, Menegakan Konstitusi. Jakarta: Rajawali Press.

News.detik.com. (2017, Juli 21). Sudah disahkan ini 5 isu krusial di UU Pemilu. Retrieved Juli 22, 2017, from https:// news.detik.com/berita/d-3568067/sudahdisahkan-ini-5-isu-krusial-di-uu-pemilu

Nurtjahjo, H. (2006). Filsafat Demokrasi. Jakarta: Bumi Aksara.
Nuryanti, S. (2015). "Menyiapkan Tata Kelola Pemilu Serentak 2019”. Jurnal Penelitian Politik, Volume 12 No. 1 Juni 2015. Hlm. 3.

Pahlevi, I.(2015). Pemilu Serentak dalam Sistem Pemerintahan Indonesia. Jakarta: P3DI Setjen DPR RI dan Azza Grafika.

Putusan Mahkamah Konstitusi Tentang Perkara Nomor 14/PUU-XI/2013 Uji Materi UU Nomor 42 Tahun 2008 Tentang Pemilu Presiden dan Wakil Presiden.

Surbakti, R. (2011). Merancang Sistem Politik Demokratis: Menuju Pemerintahan Presidensial yang Efektif. Buku I. Jakarta: Kemitraan bagi Pembaruan Tata Pemerintahan.

Tutik, T. T.(2010). Konstruksi Hukum Tata Negara Indonesia Pasca Amandemen UUD 1945. Jakarta: Prenada Media Group.

Undang Undang No. 2 Tahun 2011 Tentang Partai Politik

Yuda, H. (2010). Presidensialisme Setengah Hati dari Dilema ke Kompromi.Jakarta: PT. Gramedia Pustaka Utama. 